\title{
Effect of Foliar Application of Micronutrients and Compost Tea on Chemical Composition and the Productivity of Fenugreek Plants Under Baloza - North Sinai Conditions \\ Rehab H. Hegab
}

Soil fertility and Microbiology Department, Desert Research Center El-Mataria, Cairo, Egypt

Tel.: +2 01003452224. E-mail address: drrehabhh@yahoo.com

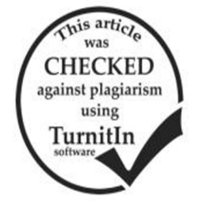

\begin{abstract}
Micronutrients are important for plant growth, but plants need relatively small amounts of them, hence, the term "micro. The present investigation was carried out at Baloza Research Station of the Desert Research Center, North Sinai, Egypt during the two successive seasons of 2017/2018 to study the effect of foliar application combination of micronutrients forms and compost tea. The experiment was conducted in a split plot design, with three replicates. The main plots were randomly assigned to compost tea (with, without), the sub plots were represented by four micronutrients spraying of $\mathrm{Fe}, \mathrm{Cu}, \mathrm{Mn}$ and $\mathrm{Zn}$, as (the two chelated forms of humic and EDTA and the mineral form). The objectives of the present study were to investigate the effect of foliar application of some chelated micronutrients and compost tea on growth and yield productivity of Fenugreek plant and macro and micro nutrient contents in herb and seed. The results showed that, the best treatments were $((\mathrm{Mn}, \mathrm{Zn}, \mathrm{Cu}, \mathrm{Fe})$ Humic form with compost tea which gave the highest yield components: the average percentage increment of dry weight of seed ( $\mathrm{g} / \mathrm{plant})$, dry weight of $\operatorname{seed}(\mathrm{kg} / \mathrm{fed}$.), fixed oil ( $\mathrm{ml} / \mathrm{plant})$ and fixed oil( $\mathrm{kg} /$ fad.) $(76.80,77.62,122.08$ and 137.9) in two season, respectively. In addition, macro and micro elements contents were significantly increased in herb and seeds. These results also indicated that the concentrations of $\mathrm{Fe}, \mathrm{Mn}, \mathrm{Zn}, \mathrm{Cu}$ in seeds and herb, of Fenugreek plants were lower the normal ranges.
\end{abstract}

Keywords: micronutrients, chelated form, Humic form, compost tea, Fenugreek yield,

\section{INTRODUCTION}

In the latest decades, medicinal plants gained a substantial importance in agricultural production, pharmacy and exportation because of their use as a raw material for the pharmaceutical industry. Fenugreek ( Trigonella foenum-graecum L.), an annual forage legume belonging to the family Fabaceae, is well identified as a herb and spice crop (Acharya et. al., 2011). Fenugreek leaves and seeds are used in many countries around the world for different purposes such as medicinal uses (antidiabetic, lowering blood sugar and cholesterol level, anticancer, anti-microbial, controlling insects in grain storages, perfume industries. Fenugreek can be a extremely useful legume crop for incorporation into short-term rotation and for hay and silage for livestock feed, for fixation of nitrogen in soil and its fertility. Fenugreek seeds have been identified and valued as medicinal material. Its seeds are considered to be of commercial interest as a source of a steroid diosgenin, which is of importance to the pharmaceutical industry (Mehrafarin et. al., 2010). Fenugreek seeds are reputed to have numerous medicinal virtues, as a tonic, emollient, carminative, demulcent, diuretic, astringent emmenagogue, expectorant, restorative, aphrodisiac and vermifugal properties and were used to cure mouth ulcers, chapped lips and stomach irritation ( Duke 1986).

Plants absorb nutrients from soils through their roots although nutrients can be supplied to plants as fertilizers by foliar sprays. Foliar fertilizer is a new and controversial technique of feeding plants by applying liquid fertilizer directly to their leaves (Bernal et. al., 2007; Baloch et. al., 2008). The application of chelated forms of micronutrients, characterized by high solubility in water and low value of dissociated constant, is crucial for the prevention of immobilization. Chelates make metal cations being slowly released to a medium solution or absorbed by plants in complexes forms (Wreesmann, 1996). As proven by Komosa et.al. (2005), durability and availability of microelements to plants depend on properties of ligands. The most ordinary chelating agents used in fertilizers include EDTA, DTPA and EDDHA (Lucena, 2003), which differ in strength of chemical bonds of the ionic and complex with metals as a function of $\mathrm{pH}$. The shortcoming of these chelating agents, especially EDTA, is their low biodegradability (Borowiec et. al. 2007, Albano and Merhaut 2012).

Micronutrients as $\mathrm{Fe}, \mathrm{Zn}, \mathrm{Mn}$ and $\mathrm{Cu}$ are involved in many physiological processes that are essential for plant, in order to compensate their deficiency especially in arid and semi aid regions (Kaya et. al., 2005).Micronutrients, $\mathrm{Fe}$ and $\mathrm{Zn}$, proceed either as metal components of various enzymes or as functional, structural, or regulatory cofactors. Thus, they are associated with saccharide metabolism, photo-synthesis, and protein synthesis Marschner (1995). Iron is essentially present in the form of insoluble Fe (III), therefore, unavailable to higher plants, mainly in neutral and alkaline soils (Shao et.al., 2007). Copper plays an important role in the metabolism of $\mathrm{N}$ compounds. Manganese, beside with $\mathrm{Zn}$, has an effect on protein biosynthesis by adjusting the activity of peptidases and controlling protein metabolism (Hänsch and Mendel, 2009). Kozik, et.al., (2008) reported that after the folair application of chelated manganese, there was more copper and iron in the lettuce, but a smaller amount of zinc than in case of manganous sulphate application.

Essential oil biosynthesis in basil (Ocimum sanctum L.) is strongly influenced by Fe and $\mathrm{Zn}$ (Misra et. al., 2006). Foliar spraying with zinc (100 ppm) in blue sage (Salvia farinacea L.) enhanced the length of peduncle, length of main inflorescence, number of inflorescence and florets, and fresh and dry weight of inflorescences/ plant (Abd El-Aziz and Balbaa, 2007).

Compost tea, a liquid organic fertilizer, contains available chelated micronutrients to absorb by plants and nutrients in suitable form to uptake by soil microorganisms and plants (Hendawy 2008) Compost tea, significantly, increased plant height $(\mathrm{cm})$, fresh and dry weight, seed weight $(\mathrm{g})$ and oil percentage in Borage plants (El-Din and Hendawy 2010). Compost tea when used as a soil drench increased the $\% \mathrm{~N}$ and \% $\mathrm{P}$ uptake rates by $126 \%$ and $255 \%$ respectively (Ibrahim and Ibrahim 2014), and 
increased carbohydrate content of turnip roots (ElSherbeny e.t al., 2012). Foliar fertilizers of Nigella plants during active vegetative growth increased yield significantly comparing with soil-applied fertilizers (Alrubaie and alzaidi 2011).

The objective of this study was conducted to investigate the effect of combination of microelements forms and compost tea on Fenugreek productivity and some macro and micro nutrients availability and contents.

\section{MATERIALS AND METHODS}

A field experiment was carried out at Baloza Research Station of the Desert Research Center, located at $31^{\circ} 3^{\prime} 0^{\prime \prime} \mathrm{N}, 32^{\circ} 36^{\prime} 0^{\prime \prime} \mathrm{E}$ on Fenugreek crop during the two successive winter growing seasons of (2016-2017) and (2017-2018) season. The study the effect of some micronutrients $(\mathrm{Fe}, \mathrm{Cu}, \mathrm{Mn}$ and $\mathrm{Zn}$ ) added in two chelated forms of (humic and EDTA) and mineral form as foliar application on Fenugreek growth, yield and its components was studied. The experiment was designed in a randomized complete block design split plot with 8 combinations, The main plots were randomly assigned to compost tea (with, without), the sub plots were subjected to mixture of some micronutrients ( $\mathrm{Fe}, \mathrm{Cu}, \mathrm{Mn}$ and $\mathrm{Zn})$ ) added in chelated forms of( Humic and EDTA), mineral forms and without as (control), added as foliar application, each treatment included three replicates. Micronutrients solution was as sulfate form with concentration: $300 \mathrm{mg} \mathrm{L}$ 1 for Fe, $100 \mathrm{mg} \mathrm{L}-1$ for Mn, $50 \mathrm{mg} \mathrm{L}-1$ for Zn, and $50 \mathrm{mg}$ L-1 for $\mathrm{Cu}$. The chelating agents were EDTA and humic acid. Aerated compost tea produced by mixing mature compost made by El-Arabeya for Organic Fertilizer Factory with distilled water in ratio of $1: 5(\mathrm{w} / \mathrm{v})$ and supplemented with $2 \%$ molasses for microbial growth stimulation. The entire contents were continuously aerated at room temperature with a fish-tank bubbling-pump for 72 hours, The chemical analysis of the used compost tea is shown in Table (1).

Table 1. Nutrient contents of compost tea

\begin{tabular}{lcccccc}
\hline \multicolumn{7}{c}{ Nutrients $\mathbf{~ m g / l}$} \\
\hline $\mathbf{N}$ & $\mathbf{P}$ & $\mathbf{K}$ & $\mathbf{F e}$ & $\mathbf{Z n}$ & $\mathbf{M n}$ & $\mathbf{C u}$ \\
\hline 2025 & 289 & 1725 & 1.36 & 1.95 & 0.86 & $* \mathrm{~N}$ \\
\hline
\end{tabular}

*N=not detected

All treatments and the control were applied at the tillering stage ( 35 days from sowing) and at the booting stage (70 days from sowing). The experimental field was irrigated by drip irrigation system. Fenugreek Seed were sowing during $15^{\text {th }}$ November in rows spacing $50 \mathrm{~cm}$ apart and $15 \mathrm{~cm}$ between seed hills (17500 plant/fed). All treatments received $18 \mathrm{~kg} \mathrm{~K}_{2} \mathrm{O} / \mathrm{fed}$ as potassium sulfate was applied in two equal doses while $15 \mathrm{~kg} \mathrm{~N} / \mathrm{fed}$ as ammonium sulfate and Phosphorus was applied as super phosphate $\left(15.5 \% \mathrm{P}_{2} \mathrm{O}_{5}\right)$ at the rate of $48 \mathrm{~kg} \mathrm{P}_{2} \mathrm{O}_{5}$ fed $^{-1}$ during the soil preparation. The other agricultural practices were done as the recommendation of Ministry of Agriculture. Fenugreek plants were harvested at maturity at the end of April. Soil samples were collected from the studied plots at two depths $(0-30 \mathrm{~cm}$ and $30-60 \mathrm{~cm})$ before initiating the experiment for physical and chemical analysis The mechanical and chemical properties of the used soil are shown in Table (2) according to (Page et al., 1984).
Table 2. Some chemical and physical properties of the experimental soil

\begin{tabular}{lcc}
\hline Depth & $\mathbf{0 - 3 0} \mathbf{~ c m}$ & $\mathbf{3 0 - 6 0 ~ c m}$ \\
\hline Particle size distribution \% & & \\
Sand & 89.12 & 90.73 \\
Silt & 6.34 & 5.56 \\
Clay & 4.54 & 3.71 \\
\hline Texture class & sandy & sandy \\
pH saturated soil paste & 8.20 & 8.06 \\
EC(ds/m) & 1.37 & 1.21 \\
\hline Soluble ions in saturated soil extract & & \\
(meq/L) & & \\
$\mathrm{Na}$ & 5.13 & 2.84 \\
$\mathrm{~K}$ & 0.54 & 3.91 \\
$\mathrm{Ca}$ & 3.65 & 4.89 \\
$\mathrm{Mg}$ & 4.40 & 0.48 \\
$\mathrm{Cl}$ & 3.30 & 3.12 \\
$\mathrm{HCO}$ & 3.85 & 3.54 \\
$\mathrm{SO}_{4}$ & 6.57 & 5.47 \\
$\mathrm{Available} \mathrm{nutrients}(\mathrm{mg} / \mathrm{kg})$ & & \\
$\mathrm{N}$ & 35 & 27 \\
$\mathrm{P}$ & 2.66 & 1.74 \\
$\mathrm{~K}$ & 44 & 32 \\
\hline
\end{tabular}

The applied irrigation water was added through trickle irrigation system with the drippers of four liters/hr for half an hour every day. The chemical analysis of the used water for El-Salam Canal irrigation is shown in Table (3). At harvesting stage, plants were harvested at the end of April. Crop was harvested manually. Grains were separated from straw and weighed in the field, the following data were recoded

\section{Growth and Yield characters:}

Plant height $(\mathrm{cm})$, seed weight per plant $(\mathrm{g})$, seed weight per plant $(\mathrm{kg} / \mathrm{fed})$ and oil content $(\mathrm{ml} / \mathrm{plant})$ and (L/fed) of Fenugreek were isolated using a Clevenger-type apparatus according to British Pharmacopoeia, (1963).

\section{Plant analysis}

Plant samples including straw and seeds were thoroughly washed and dried at $70{ }^{\circ} \mathrm{C}$. Plant samples were wet digested using $\mathrm{H}_{2} \mathrm{O}_{2}$ and $\mathrm{H}_{2} \mathrm{SO}_{4}$ according to procedure described by Nicholson (1984). N, P and K were determined in acid digested solution, which was prepared according to Cottenie et. al., (1982). Total heavy metals content were determined using Ionic Coupled Argon Plasma according to Ure,( 1995).

Table 3. physicochemical composition of El-Salam Canal irrigation water in Baloza Station

\begin{tabular}{lcc}
\hline Parameter & $\begin{array}{c}\text { Irrigation } \\
\text { water }\end{array}$ & $\begin{array}{c}\text { Permissible Limit For } \\
\text { irrigation }\end{array}$ \\
\hline $\mathrm{pH}$ & 8 & $\begin{array}{c}\text { Normal range 6.5-8.40 } \\
<3.00 \mathrm{dsm}^{-1}\end{array}$ \\
$\mathrm{EC}\left(\mathrm{dsm}^{-1}\right)$ & 2.8 & \\
$\mathrm{Ca}^{2+}\left(\mathrm{mgl}^{-1}\right)$ & 80.16 & \\
$\mathrm{Mg}^{2+}\left(\mathrm{mgl}^{-1}\right)$ & 72.95 & \\
$\mathrm{Na}^{+}\left(\mathrm{mgl}^{-1}\right)$ & 407.08 & \\
$\mathrm{~K}^{+}\left(\mathrm{mgl}^{-1}\right)$ & 31.37 & \\
$\mathrm{CO}_{3}^{2-}\left(\mathrm{mgl}^{-1}\right)$ & -- & \\
$\mathrm{HCO}_{3}^{-1}\left(\mathrm{mgl}^{-1}\right)$ & 73.22 & \\
$\mathrm{Cl}^{-1}\left(\mathrm{mgl}^{-1}\right)$ & 815.60 & - \\
$\mathrm{SO}_{4}^{2-}\left(\mathrm{mgl}^{-1}\right)$ & 206.73 & $0.01^{*}$ \\
$\mathrm{Al}\left(\mathrm{mgl}^{-1}\right)$ & n.d. & $0.05^{*}$ \\
$\mathrm{Cd}\left(\mathrm{mgl}^{-1}\right)$ & 0.01 & $0.2^{*}$ \\
$\mathrm{Co}\left(\mathrm{mgl}^{-1}\right)$ & n.d. & $5.0^{*}$ \\
$\mathrm{Cu}\left(\mathrm{mgl}^{-1}\right)$ & n.d. & - \\
$\mathrm{Fe}\left(\mathrm{mgl}^{-1}\right)$ & n.d. & - \\
$\mathrm{Mn}\left(\mathrm{mgl}^{-1}\right)$ & n.d. & \\
$\mathrm{Mo}\left(\mathrm{mgl}^{-1}\right)$ & 0.0048 & 58 \\
$\mathrm{Ni}\left(\mathrm{mgl}^{-1}\right)$ & 0.001 & \\
$\mathrm{~Pb}\left(\mathrm{mgl}^{-1}\right)$ & n.d. & \\
\hline
\end{tabular}

*FAO for irrigation water (Ayers and Wescot, 1994) 


\section{Statistical analysis:}

Data of the present work were statistically analyzed and the differences between the means of the treatments were considered significant when they were more than the least significant differences (L.S.D) at the 5\% level by using computer program of Statistix version 9 (Analytical software, 2008).

\section{RESULTS AND DISCUSSION}

\section{Growth and Yield characters}

Data in Table (4) show that the yield of Fenugreek plants was significantly affected by the studied different treatments through two seasons. Foliar application with micronutrients forms recorded significant differences in all parameters under the study. Application of humic form gave significantly higher increase than EDTA and mineral form. The combined use of humate and metal chelates seems to have a greater potential rather than metal only. Micronutrients play main roles in the release of carbon dioxide, and in optimizing the function of vitamin A and the immune system, Where Chelates are much more easily absorbed by plant leaves because chelates are of organic nature. The chelation process removes the positive charge from the micro nutrients allow the negatively charged chelates to fall through the pores on the leaf surface more rapidly, as stated by Marschner (1995). Similar trends were reported by El-Saady (2012) ; Gad El-Hak et al. (2012) and Faizy et. al.,(2017) who reported that foliar with humic form was significantly effects higher on grain yield (16.08 and 16.55 ardab fed- 1), straw yield (3.32 and 3.06 ton fed1) and 1000 grain weight (49.15 and $47.51 \mathrm{gm}$ ) in the first and second seasons. (Raza et al., (2014), reported that the grain yield of wheat increased due to the application of $\mathrm{Fe}$ and B solitary or association with other micronutrients. Fenugreek plants which were sprayed with compost tea gave significantly higher increase in plant height, seed dry weights/ plant and fed than without C.T. in two seasons. These results were in agreement with those found by Eldin and Hendawy (2010) on Borage plants. Where, Compost tea contains many useful microbes and nutrients of compost but more easily applied to plants, and could be used as an agent for promoting plant growth. The interaction of chelates forms with compost tea was the superior treatment showed significantly higher increase of yield comparing with chelated forms alone. The chelated humic interacted with compost tea increased the seed dry weight $\mathrm{kg} /$ fed by $90.13 \%$ and $65.10 \%$ at season 1 and 2 , respectively, while chelated humic alone increased it only by $50.24 \%$ and $33.27 \%$ at season 1 and 2 .

Fixed oil production

Fenugreek fixed oil content / plant and Feddan significantly increased by foliar application with micronutrients forms, Application of Humic form gave significantly higher increase than EDTA and mineral form in both seasons as listed in Table 5. Sprayed with C.T. gave significant higher increase in oil content / plant and Feddan than without C.T. in two seasons. Similar trends were reported by El-din and Hendawy (2010) on Borage plants. The interaction of chelates forms with compost tea was the superior treatment showed significant higher increase of yield comparing with chelated forms alone. The chelated humic interacted with compost tea increased the Fixed oil yield / fed $(\mathrm{Kg})$ by $131.1 \%$ and $144.6 \%$ at season 1 and 2, respectively, while chelated humic alone increased it only by $84.5 \%$ and $88.6 \%$ at season 1 and 2 .

Table 4. Effect of the studied treatments on plant height, seed dry weight/plant and seed dry weight /plant Fenugreek plant during the two seasons (2017- 2018).

\begin{tabular}{|c|c|c|c|c|c|c|c|}
\hline \multirow{2}{*}{\multicolumn{2}{|c|}{ Treatments }} & \multicolumn{2}{|c|}{$\begin{array}{l}\text { plant height } \\
\text { (cm) }\end{array}$} & \multicolumn{2}{|c|}{$\begin{array}{c}\text { Seed dry } \\
\text { Weight /plant (g) }\end{array}$} & \multicolumn{2}{|c|}{$\begin{array}{c}\text { Seed dry } \\
\text { weight / fed (Kg) }\end{array}$} \\
\hline & & 2017 & 2018 & 2017 & 2018 & 2017 & 2018 \\
\hline \multicolumn{8}{|c|}{ Effect of compost tea: } \\
\hline with C.T & & 45.6 & 46.4 & 11.9 & 12.3 & 208.1 & 215.3 \\
\hline without C.T & & 35.0 & 35.5 & 9.2 & 9.8 & 160.4 & 171.7 \\
\hline LSD 0.05 & & 1.1 & 1.2 & 0.8 & 0.5 & 14.8 & 8.3 \\
\hline \multicolumn{8}{|c|}{ Effect of micronutrients: } \\
\hline control & & 33.1 & 33.6 & 8.2 & 9.2 & 143.2 & 160.9 \\
\hline$(\mathrm{Mn}, \mathrm{Zn}, \mathrm{Cu}, \mathrm{F}$ & eral form & 38.7 & 39.5 & 10.2 & 10.5 & 178.4 & 183.8 \\
\hline$(\mathrm{Mn}, \mathrm{Zn}, \mathrm{Cu}, \mathrm{F}$ & nic form & 46.0 & 46.7 & 12.4 & 12.9 & 216.5 & 226.0 \\
\hline$(\mathrm{Mn}, \mathrm{Zn}, \mathrm{Cu}, \mathrm{F}$ & TA form & 43.7 & 44.1 & 11.4 & 11.6 & 199.0 & 203.3 \\
\hline LSD 0.05 & & 1.2 & 1.0 & 0.7 & 0.4 & 12.4 & 6.6 \\
\hline \multicolumn{8}{|c|}{ Effect of interaction:- } \\
\hline without C.T & control & 30.5 & 30.8 & 7.3 & 8.7 & 127.2 & 151.5 \\
\hline without C.T & $(\mathrm{Mn}, \mathrm{Zn}, \mathrm{Cu}, \mathrm{Fe})$ mineral form & 31.8 & 32.7 & 8.5 & 8.8 & 149.4 & 153.7 \\
\hline without C.T & $(\mathrm{Mn}, \mathrm{Zn}, \mathrm{Cu}, \mathrm{Fe})$ Humic form & 40.9 & 41.5 & 10.9 & 11.5 & 191.1 & 201.9 \\
\hline without C.T & $(\mathrm{Mn}, \mathrm{Zn}, \mathrm{Cu}, \mathrm{Fe}) \mathrm{EDTA}$ form & 36.7 & 37.1 & 9.9 & 10.3 & 174.1 & 179.7 \\
\hline with C.T & control & 35.7 & 36.5 & 9.1 & 9.7 & 159.3 & 170.4 \\
\hline with C.T & $(\mathrm{Mn}, \mathrm{Zn}, \mathrm{Cu}, \mathrm{Fe})$ mineral form & 45.1 & 46.2 & 11.8 & 12.2 & 207.3 & 213.9 \\
\hline with C.T & $(\mathrm{Mn}, \mathrm{Zn}, \mathrm{Cu}, \mathrm{Fe}) \mathrm{Humic}$ form & 51.1 & 51.9 & 13.8 & 14.3 & 241.9 & 250.1 \\
\hline with C.T & $(\mathrm{Mn}, \mathrm{Zn}, \mathrm{Cu}, \mathrm{Fe}) \mathrm{EDTA}$ form & 50.8 & 51.0 & 12.8 & 13.0 & 223.9 & 226.9 \\
\hline LSD 0.05 & & 1.7 & 1.6 & 1.2 & 0.6 & 20.2 & 11.0 \\
\hline
\end{tabular}


Table 5. Effect of the studied treatments on Fixed oil yield / fed (Kg) and Fixed oil ml/plant of Fenugreek plant during the two seasons (2017-2018)

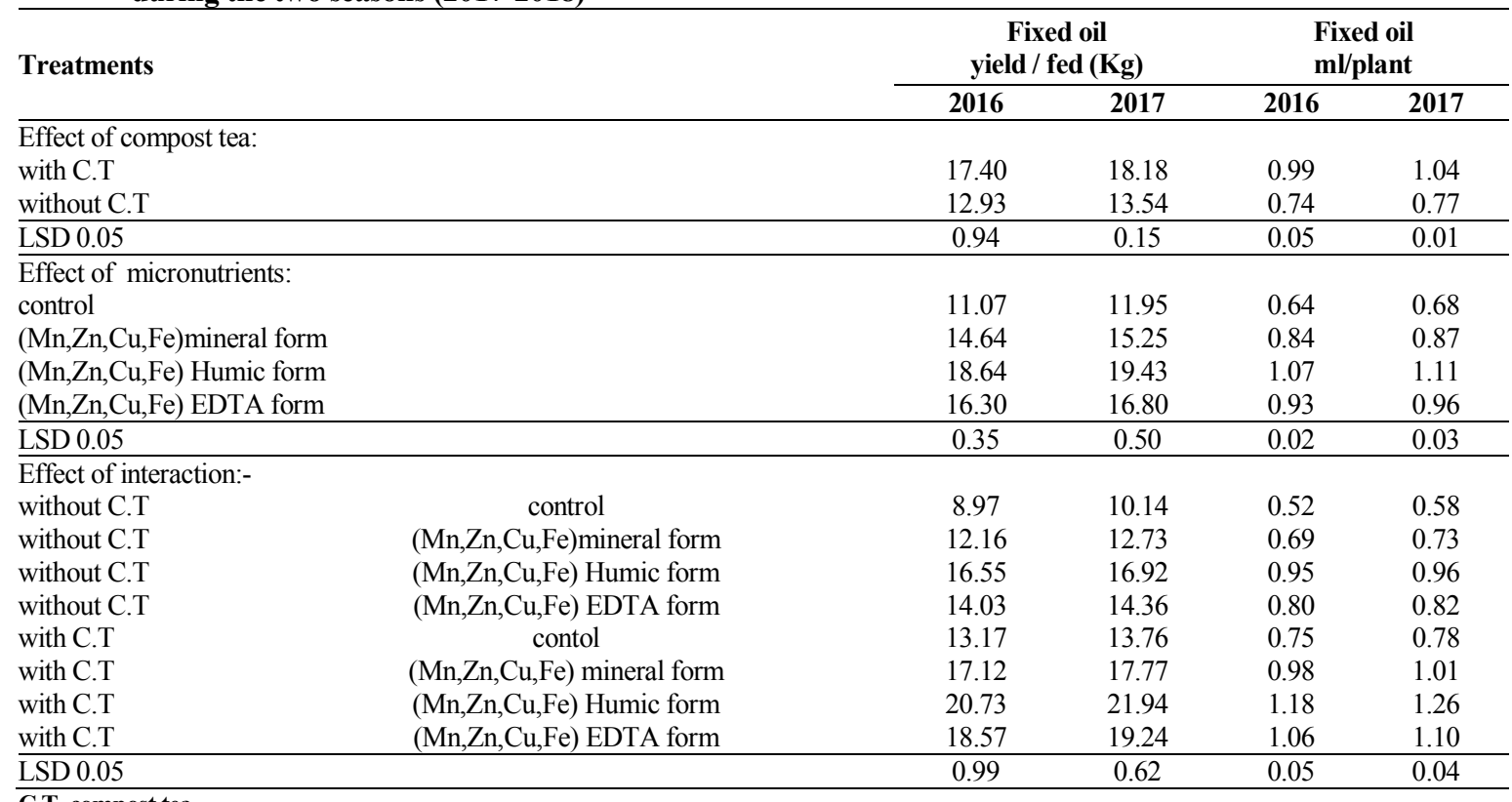

C.T. compost tea

$\mathrm{N}, \mathrm{P}, \mathrm{K}, \mathrm{Ca}$ and Mg content in dry seed and herb of plant

It is clear from data in Table $(6,7)$ that the macronutrients status of Fenugreek plants significantly affected by the studied different treatments through the two seasons. Foliar application with micronutrients forms recorded significant differences in all parameters under the study. Application of humic form gave significantly higher results than EDTA and mineral form. It may be due to humus stimulating effect on absorption of the nutrients, where Chelates forms are easily assimilated within the plant system. Similar trends were reported by Wojtkowiak et al. (2014). Fenugreek plants which were sprayed with C.T. gave significant higher increase in $\mathrm{N}, \mathrm{P}, \mathrm{K}, \mathrm{Ca}$ and
$\mathrm{Mg}$ content than without C.T. in the two seasons. Compost tea enhancing the uptake and accumulation of nutrient elements in the plant (Rodríguez-Ortíz et. al., 2006), Foliar application of compost tea increased the time stomata stay open, reducing loss from the leaf surface, so the availability of mineral nutrients is higher for foliar than drench application ( Mahmoud et. al., 2014) . The interaction of humic forms with compost tea was the superior treatment which recorded significant increases $(2.99,3.33,0.38$, $0.41,1.58,1.65,0.39,0.41,0.23$ and $0.24 \%$ in seeds). Also, in herb was $(2.40,2.44,0.21,0.22,1.89,2.13,1.16$, $1.21,0.42$ and $0.44 \%$ ) for $\mathrm{N}, \mathrm{P}, \mathrm{K}, \mathrm{Ca}$ and $\mathrm{Mg}$ content in season 1 and 2, respectively.

Table 6. Effect of the studied treatments on $\mathrm{N}, \mathrm{P}, \mathrm{K}, \mathrm{Ca}$ and $\mathrm{Mg} \%$ in dry herb of Fenugreek plant during the two seasons (2017-2018).

\begin{tabular}{|c|c|c|c|c|c|c|c|c|c|c|}
\hline \multirow{2}{*}{ treatments } & \multicolumn{2}{|c|}{$\mathbf{N \%}$} & \multicolumn{2}{|c|}{$\mathbf{P} \%$} & \multicolumn{2}{|c|}{$\mathbf{K} \%$} & \multicolumn{2}{|c|}{$\mathbf{C a} \%$} & \multicolumn{2}{|c|}{ Mg\% } \\
\hline & 2017 & 2018 & 2017 & 2018 & 2017 & 2018 & 2017 & 2018 & 2017 & 2018 \\
\hline $\begin{array}{l}\text { Effect of compost tea: } \\
\text { with C.T }\end{array}$ & 1.89 & 1.93 & 0.15 & 0.16 & 1.57 & 1.66 & 1.02 & 1.07 & 0.39 & 0.41 \\
\hline without C.T & 1.28 & 1.30 & 0.11 & 0.12 & 1.29 & 1.36 & 0.74 & 0.77 & 0.31 & 0.33 \\
\hline LSD 0.05 & 0.16 & 0.02 & 0.02 & 0.01 & 0.08 & 0.02 & 0.05 & 0.02 & 0.02 & 0.01 \\
\hline $\begin{array}{l}\text { Effect of micronutrients: } \\
\text { control }\end{array}$ & 0.94 & 0.96 & 0.08 & 0.09 & 0.74 & 0.78 & 0.69 & 0.72 & 0.32 & 0.33 \\
\hline$(\mathrm{Mn}, \mathrm{Zn}, \mathrm{Cu}, \mathrm{Fe})$ mineral form & 1.58 & 1.61 & 0.12 & 0.13 & 1.49 & 1.58 & 0.89 & 0.92 & 0.34 & 0.36 \\
\hline$(\mathrm{Mn}, \mathrm{Zn}, \mathrm{Cu}, \mathrm{Fe}) \mathrm{Humic}$ form & 2.00 & 2.03 & 0.17 & 0.18 & 1.80 & 1.91 & 1.01 & 1.05 & 0.38 & 0.40 \\
\hline$(\mathrm{Mn}, \mathrm{Zn}, \mathrm{Cu}, \mathrm{Fe}) \mathrm{EDTA}$ form & 1.82 & 1.85 & 0.15 & 0.16 & 1.69 & 1.79 & 0.95 & 0.99 & 0.36 & 0.37 \\
\hline LSD 0.05 & 0.07 & 0.01 & 0.01 & 0.00 & 0.06 & 0.02 & 0.01 & 0.01 & 0.00 & 0.00 \\
\hline $\begin{array}{l}\text { Effect of interaction:- } \\
\text { without C.T control }\end{array}$ & 0.87 & 0.89 & 0.08 & 0.08 & 0.66 & 0.70 & 0.53 & 0.55 & 0.28 & 0.30 \\
\hline$(\mathrm{Mn}, \mathrm{Zn}, \mathrm{Cu}, \mathrm{Fe})$ mineral form & 1.19 & 1.20 & 0.11 & 0.12 & 1.41 & 0.86 & 0.79 & 0.82 & 0.31 & 0.32 \\
\hline$(\mathrm{Mn}, \mathrm{Zn}, \mathrm{Cu}, \mathrm{Fe})$ Humic form & 1.59 & 1.62 & 0.13 & 0.14 & 1.59 & 1.68 & 0.85 & 0.89 & 0.34 & 0.36 \\
\hline$(\mathrm{Mn}, \mathrm{Zn}, \mathrm{Cu}, \mathrm{Fe}) \mathrm{EDTA}$ form & 1.46 & 1.48 & 0.12 & 0.13 & 1.49 & 1.58 & 0.80 & 0.83 & 0.31 & 0.32 \\
\hline with C.T & 1.01 & 1.03 & 0.09 & 0.09 & 0.81 & 0.86 & 0.85 & 0.89 & 0.35 & 0.37 \\
\hline$(\mathrm{Mn}, \mathrm{Zn}, \mathrm{Cu}, \mathrm{Fe})$ mineral form & 1.97 & 2.01 & 0.14 & 0.14 & 2.01 & 1.66 & 0.98 & 1.02 & 0.37 & 0.39 \\
\hline$(\mathrm{Mn}, \mathrm{Zn}, \mathrm{Cu}, \mathrm{Fe})$ Humic form & 2.40 & 2.44 & 0.21 & 0.22 & 1.89 & 2.13 & 1.16 & 1.21 & 0.42 & 0.44 \\
\hline$(\mathrm{Mn}, \mathrm{Zn}, \mathrm{Cu}, \mathrm{Fe})$ EDTA form & 2.18 & 2.22 & 0.17 & 0.18 & 1.56 & 2.00 & 1.09 & 1.14 & 0.40 & 0.42 \\
\hline$\overline{L S D} 0.05$ & 0.17 & 0.02 & 0.02 & 0.01 & 0.11 & 0.02 & 0.05 & 0.02 & 0.02 & 0.01 \\
\hline
\end{tabular}


Table 7. Effect of the studied treatments on N, P, K, Ca and Mg \% in dry seed of Fenugreek plant during the two seasons (2017-2018).

\begin{tabular}{|c|c|c|c|c|c|c|c|c|c|c|}
\hline \multirow{2}{*}{ treatments } & \multicolumn{2}{|c|}{$\mathbf{N \%}$} & \multicolumn{2}{|c|}{$\mathbf{P \%}$} & \multicolumn{2}{|c|}{$\mathbf{K} \%$} & \multicolumn{2}{|c|}{$\mathbf{C a} \%$} & \multicolumn{2}{|c|}{ Mg\% } \\
\hline & 2017 & 2018 & 2017 & 2018 & 2017 & 2018 & 2017 & 2018 & 2017 & 2018 \\
\hline $\begin{array}{l}\text { Effect of compost tea: } \\
\text { with } C T\end{array}$ & 2.50 & 2.69 & 0.30 & 0.33 & 1.33 & 1.38 & 0.35 & 0.36 & 0.21 & 0.22 \\
\hline without C.T & 2.19 & 2.36 & 0.24 & 0.26 & 1.13 & 1.18 & 0.28 & 0.29 & 0.18 & 0.18 \\
\hline LSD 0.05 & 0.112 & 0.022 & 0.031 & 0.016 & 0.033 & 0.007 & 0.016 & 0.009 & 0.012 & 0.007 \\
\hline $\begin{array}{l}\text { Effect of micronutrients: } \\
\text { control }\end{array}$ & 1.98 & 2.13 & 0.20 & 0.22 & 1.08 & 1.13 & 0.27 & 0.28 & 017 & 018 \\
\hline$(\mathrm{Mn}, \mathrm{Zn}, \mathrm{Cu}, \mathrm{Fe})$ mineral form & 2.28 & 2.46 & 0.26 & 0.28 & 1.17 & 1.22 & 0.30 & 0.31 & 0.19 & 0.20 \\
\hline$(\mathrm{Mn}, \mathrm{Zn}, \mathrm{Cu}, \mathrm{Fe})$ Humic form & 2.70 & 2.91 & 0.32 & 0.35 & 1.39 & 1.45 & 0.35 & 0.36 & 0.21 & 0.22 \\
\hline$(\mathrm{Mn}, \mathrm{Zn}, \mathrm{Cu}, \mathrm{Fe})$ EDTA form & 2.41 & 2.60 & 0.30 & 0.32 & 1.28 & 1.33 & 0.34 & 0.35 & 0.20 & 0.21 \\
\hline LSD 0.05 & 0.054 & 0.011 & 0.013 & 0.007 & 0.016 & 0.006 & 0.004 & 0.003 & 0.004 & 0.005 \\
\hline \multicolumn{11}{|l|}{ Effect of interaction:- } \\
\hline without C.T & 1.85 & 2.00 & 0.20 & 0.21 & 1.07 & 1.12 & 0.25 & 0.26 & 0.16 & 0.17 \\
\hline$(\mathrm{Mn}, \mathrm{Zn}, \mathrm{Cu}, \mathrm{Fe})$ mineral form & 2.16 & 2.33 & 0.22 & 0.25 & 1.11 & 1.16 & 0.26 & 0.27 & 0.18 & 0.18 \\
\hline$(\mathrm{Mn}, \mathrm{Zn}, \mathrm{Cu}, \mathrm{Fe})$ Humic form & 2.40 & 2.58 & 0.27 & 0.29 & 1.20 & 1.25 & 0.30 & 0.32 & 0.18 & 0.19 \\
\hline$(\mathrm{Mn}, \mathrm{Zn}, \mathrm{Cu}, \mathrm{Fe})$ EDTA form & 2.33 & 2.51 & 0.26 & 0.28 & 1.14 & 1.19 & 0.29 & 0.30 & 0.18 & 0.19 \\
\hline with C.T & 2.10 & 2.26 & 0.21 & 0.22 & 1.09 & 1.14 & 0.28 & 0.29 & 0.18 & 0.18 \\
\hline$(\mathrm{Mn}, \mathrm{Zn}, \mathrm{Cu}, \mathrm{Fe})$ mineral form & 2.40 & 2.58 & 0.29 & 0.31 & 1.22 & 1.27 & 0.34 & 0.35 & 0.23 & 0.21 \\
\hline$(\mathrm{Mn}, \mathrm{Zn}, \mathrm{Cu}, \mathrm{Fe})$ Humic form & 2.99 & 3.23 & 0.38 & 0.41 & 1.58 & 1.65 & 0.39 & 0.41 & 0.23 & 0.24 \\
\hline$(\mathrm{Mn}, \mathrm{Zn}, \mathrm{Cu}, \mathrm{Fe})$ EDTA form & 2.50 & 2.69 & 0.33 & 0.37 & 1.42 & 1.48 & 0.38 & 0.40 & 0.21 & 0.24 \\
\hline LSD 0.05 & 0.123 & 0.024 & 0.033 & 0.017 & 0.036 & 0.010 & 0.016 & 0.010 & 0.013 & 0.009 \\
\hline
\end{tabular}

C.T. compost tea

Micronutrients content in dry seed and herb of plant

It is clear from data in Tables $(8,9)$ that the micronutrients status of Fenugreek plants significantly was affected by the studied different treatments through the two seasons. Foliar application with micronutrients forms recorded significant differences in all parameters under the study. Application of humic form gave significant higher increases than EDTA and mineral form. In fact, Cakmak (2008) and Hänsch \&Mendel (2009) reported that, The advantageous action of micronutrients $(\mathrm{Mn}, \mathrm{Cu}$, and $\mathrm{Zn})$ is an effect of plant metabolism stimulation. Similar results were obtained by Narwal et. al.,( 2012) on wheat and Gomaa et al., (2015), who reported that foliar application of micronutrients significantly increased concentration of micronutrients in flag leaves and grains. Also, Fenugreek plants which were sprayed with C.T. gave significantly higher increase in $\mathrm{Fe}, \mathrm{Mn}, \mathrm{Zn}, \mathrm{Cu}$, Ni content than without C.T. in two seasons. The interaction of Humic forms with compost tea was the superior treatment which recorded significant increases $(600.08,625.51,34.81,64.16,66.88$, $7.32,7.89,6.28$ and $6.67 \mathrm{mg} / \mathrm{kg}$ in herb). Also, in seeds it was $(1262.60,1316.10,46.10,48.05,49.64,51.74,10.42$, $10.87,8.07$ and $8.56 \mathrm{mg} / \mathrm{kg}$ ) for $\mathrm{Fe}, \mathrm{Mn}, \mathrm{Zn}, \mathrm{Cu}, \mathrm{Ni}$ content in season 1 and 2, respectively. The results showed also that $\mathrm{Fe}, \mathrm{Mn}, \mathrm{Zn}, \mathrm{Cu}$, Ni concentration in Fenugreek plants accumulated in seeds $>$ herb. In view of the potential toxicity of these elements to plant, the current results indicate that the concentrations of $\mathrm{Fe}, \mathrm{Mn}, \mathrm{Zn}, \mathrm{Cu}$ in seeds and herb, of Fenugreek plants were lower the normal ranges except $\mathrm{Ni}$ exceeded the normal ranges reported by Kabata-Pendias \& Pendias (1992)and Reeves \& Baker (2000).

Table 8. Effect of the studied treatments on Fe, $\mathrm{Mn}, \mathrm{Zn}, \mathrm{Cu}, \mathrm{Ni} \mathrm{mg} / \mathrm{kg}$ in dry herb of Fenugreek plant during the two seasons (2017-2018)

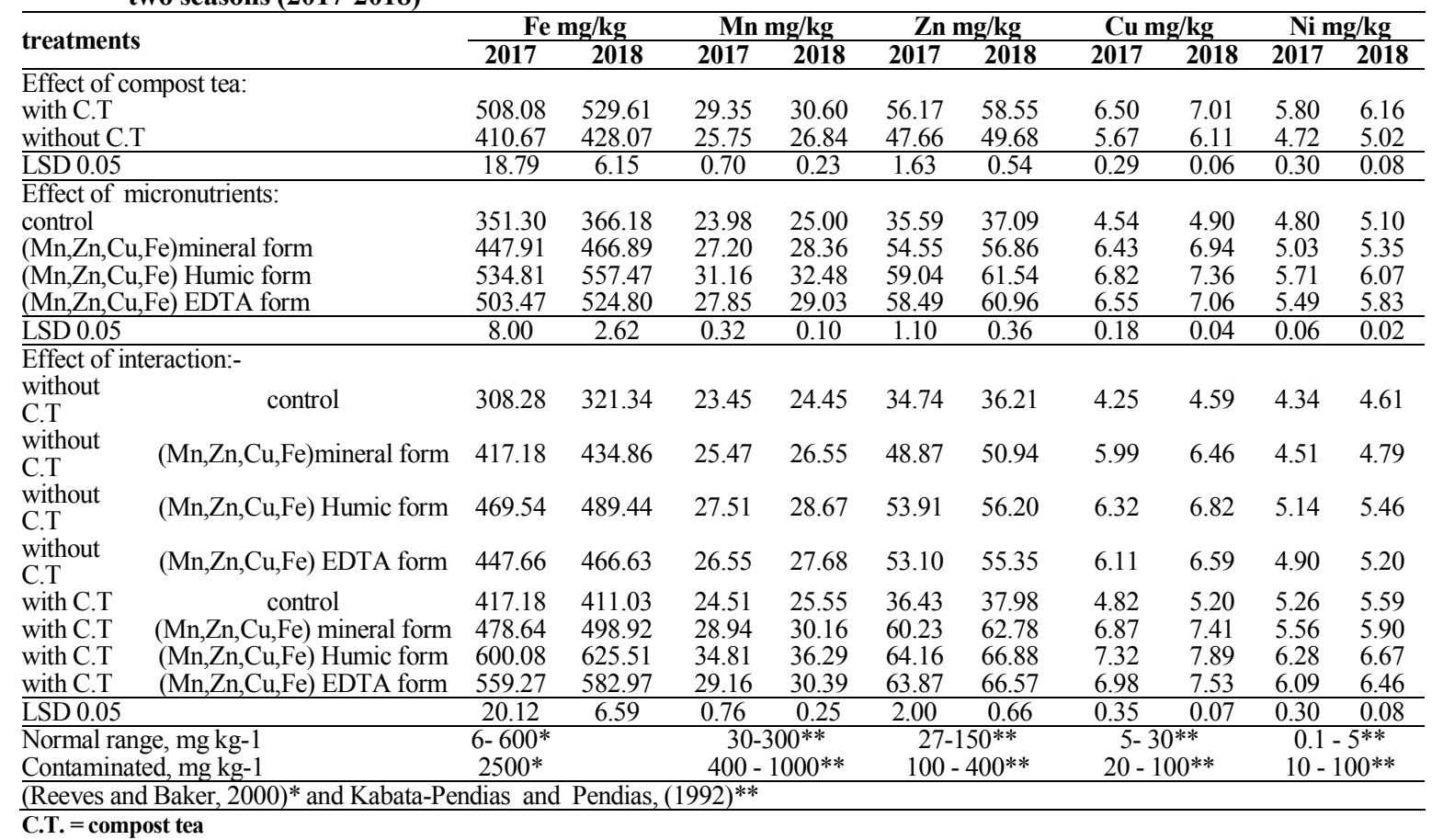


Table 9. Effect of the studied treatments on $\mathrm{Fe}, \mathrm{Mn}, \mathrm{Zn}, \mathrm{Cu}, \mathrm{Ni} \mathrm{mg/kg}$ in dry seed of Fenugreek plant during the two seasons (2017-2018)

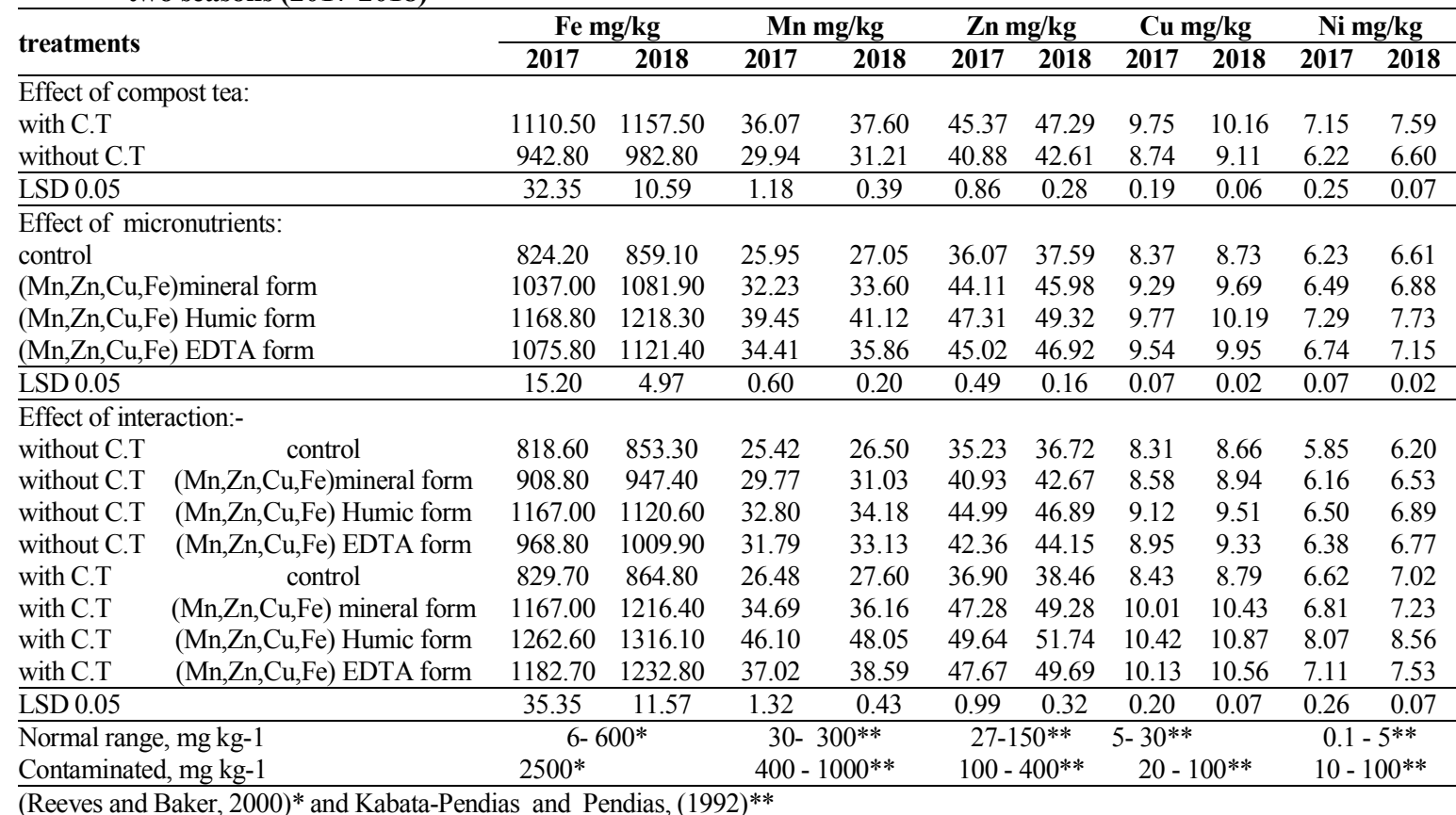

C.T. $=$ compost tea

Correlations between micronutrient content in( seed and herb) and Seed yield and oil fixed content of Fenugreek plant in average two season.

Pearson s Product-Moment correlation analysis between micronutrient content in seed in and seed yield and oil fixed content were presented in Table (10). Yield of seed in Fenugreek plant showed a strong positive and significant correlation with $\mathrm{Cu}$ content in the seed $(\mathrm{r}$ $=0.903)$, Mn content $(r=0.908)$, Fe content $(r=0.937), \mathrm{Zn}$ content $(0.908)$ and $\mathrm{Ni}$ content $(\mathrm{r}=0.896)$. Also, a strong positive correlation with seed yield and micronutrient content in herb, Fe content( $\mathrm{r}=0.933), \quad \operatorname{Mn}(0.898)$, $\mathrm{Cu}(\mathrm{r}=0.833), \mathrm{Zn}(\mathrm{r}=0.872)$ and $\mathrm{Ni}(\mathrm{r}=0.889)$. Svečnjak et. al., (2013) and Stepien \& Wojtkowiak (2016) confirmed the positive relationship between micronutrient content and seed yield. However, oil fixed content was highly positive significant with available $\mathrm{Cu}$ in seed $(\mathrm{r}=0.892), \mathrm{Mn}$ in seed $(\mathrm{r}=0.916), \mathrm{Fe}$ in seed( $\mathrm{r}=0.936), \mathrm{Zn}$ in seed $(\mathrm{r}=0.916), \mathrm{Ni}$ in seed $(r=0.913), F e$ in herb $(r=0.959), \mathrm{Mn}$ in herb $(\mathrm{r}=0.908), \mathrm{Zn}$ in herb(r=0.883), $\mathrm{Cu}$ in herb(r=0.865) and $\mathrm{Ni}$ in herb $(\mathrm{r}=0.895)$

Table 10. Correlations between micronutrient content in(seed and herb) and seed yield and oil fixed content of Fenugreek plant.

\begin{tabular}{|c|c|c|c|c|c|c|c|c|c|c|c|c|}
\hline & $\begin{array}{c}\text { yield of } \\
\text { Seed }\end{array}$ & $\begin{array}{c}\text { oil } \\
\text { content }\end{array}$ & $\begin{array}{l}\mathrm{Fe} \text { in } \\
\text { seed }\end{array}$ & $\begin{array}{c}\text { Mn in } \\
\text { seed }\end{array}$ & $\begin{array}{c}\mathrm{Zn} \text { in } \\
\text { seed }\end{array}$ & $\begin{array}{c}\mathrm{Cu} \text { in } \\
\text { seed }\end{array}$ & $\begin{array}{l}\text { Ni in } \\
\text { seed }\end{array}$ & $\begin{array}{l}\text { Fe in } \\
\text { Herb }\end{array}$ & $\begin{array}{l}\text { Mn in } \\
\text { Herb }\end{array}$ & $\begin{array}{l}\text { Zn in } \\
\text { Herb }\end{array}$ & $\begin{array}{l}\text { Cu in } \\
\text { Herb }\end{array}$ & $\begin{array}{l}\text { Ni in } \\
\text { Herb }\end{array}$ \\
\hline yield of Seed & 1 & & & & & & & & & & & \\
\hline oil content & $0.981^{* *}$ & 1 & & & & & & & & & & \\
\hline $\mathrm{Fe}$ in seed & $0.937^{* *}$ & $0.936^{* *}$ & 1 & & & & & & & & & \\
\hline Mn in seed & $0.908^{* *}$ & $0.916^{* *}$ & $0.931^{* *}$ & 1 & & & & & & & & \\
\hline $\mathrm{Zn}$ in seed & $0.908^{* *}$ & $0.916^{* *}$ & $0.931^{* *}$ & $1.000^{* *}$ & 1 & & & & & & & \\
\hline $\mathrm{Cu}$ in seed & $0.903^{* *}$ & $0.892^{* *}$ & $0.973^{* *}$ & $0.912^{* *}$ & $0.912^{* *}$ & 1 & & & & & & \\
\hline $\mathrm{Ni}$ in seed & $0.896^{* *}$ & $0.913^{* *}$ & $0.983^{* *}$ & $0.911^{* *}$ & $0.911^{* *}$ & $0.949^{* *}$ & 1 & & & & & \\
\hline Fe in Herb & $0.933^{* *}$ & $0.959^{* *}$ & $0.934^{* *}$ & $0.945^{* *}$ & $0.945^{* *}$ & $0.914^{* *}$ & $0.942^{* *}$ & 1 & & & & \\
\hline Mn in Herb & $0.898^{* *}$ & $0.908^{* *}$ & $0.928^{* *}$ & $0.992^{* *}$ & $0.992^{* *}$ & $0.921^{* *}$ & $0.905^{* *}$ & $0.927^{* *}$ & 1 & & & \\
\hline $\mathrm{Zn}$ in Herb & $0.872^{* *}$ & $0.883^{* *}$ & $0.955^{* *}$ & $0.881^{* *}$ & $0.881^{* *}$ & $0.914^{* *}$ & $0.980^{* *}$ & $0.929^{* *}$ & $0.853^{* *}$ & 1 & & \\
\hline $\mathrm{Cu}$ in Herb & $0.833^{* *}$ & $0.865^{* *}$ & $0.936^{* *}$ & $0.879^{* *}$ & $0.879^{* *}$ & $0.909^{* *}$ & $0.981^{* *}$ & $0.928^{* *}$ & $0.869^{* *}$ & $0.975^{* *}$ & 1 & \\
\hline Ni in Herb & $0.889^{* *}$ & $0.895^{* *}$ & $0.857^{* *}$ & $0.843^{* *}$ & $0.843^{* *}$ & $0.910^{* *}$ & $0.822^{* *}$ & $0.901^{* *}$ & $0.864^{* *}$ & $0.760^{* *}$ & $0.781^{* *}$ & 1 \\
\hline
\end{tabular}

**. Correlation is significant at the 0.01 level (2-tailed).

\section{CONCLUSION}

Previous results showed that the application of chelate forms combination of micronutrients $(\mathrm{Fe}, \mathrm{Cu}, \mathrm{Zn}$, $\mathrm{Mn}$ ) significantly increase yield components and improved the nutritional status of Fenugreek plant compared to mineral forms of these nutrients. In addition, the use of compost tea improves the growth of the plant. Also, It could be recommended that, Fenugreek plants should be treated by interaction of $(\mathrm{Fe}, \mathrm{Cu}, \mathrm{Zn}, \mathrm{Mn})$. Humic form with compost tea was the superior treatment showed significantly higher increase of Fenugreek Seed dry weight, Fixed oil and Macro and Micro nutrients status comparing with chelated forms alone in two season under sandy soil. The results showed also that $\mathrm{Fe}, \mathrm{Mn}, \mathrm{Zn}, \mathrm{Cu}, \mathrm{Ni}$ concentration in Fenugreek plants accumulated in seeds $>$ herb. The results indicate also that the concentrations of $\mathrm{Fe}$, $\mathrm{Mn}, \mathrm{Zn}, \mathrm{Cu}$ in seeds and herb, of Fenugreek plants were lower the normal ranges except $\mathrm{Ni}$ exceeded the normal range 


\section{REFERENCES}

Abd El-Aziz, N.G., Balbaa, L.K. (2007). Influence of tyrosine and zinc on growth, flowering and chemical constituents of Salvia farinacea plants. J. Appl. Sci. Res., 3(11): 1479-1489.

Acharya S. N.; Acharya K.;Paul S., and Basu S. K. (2011). Antioxidant and antileukemic properties of selected fenugreek (Trigonella foenum-graecum L.) genotypes grown in western Canada. Can. J. Plant Sci.) 91: 99-105

Albano, J.P.and Merhaut, D.J. (2012). Influence of FeEDDS, FeEDTA, FeDTPA, FeEDDHA and FeSO4 on marigold growth and nutrition and substrate runoff chemistry. Hort Sci., 47(1): 93-97. 646

Alrubaie, J. H. and Alzaidi, R. E. K .(2011). Effect of different nitrogen fertilizers doses and foliar fertilizers application on growth and yield of black cumin Nigella sativa. Journal of Thi-Qar University. 6(2): 65-78.

Analytical software, (2008). Statistix Version 9, Analytical Software, Tallahassee, Florida, USA. Arch. Agron. Soil Sci. 61: 185-201

Arch. Agron. Soil Sci. 61: 185-201.

Ayers, R.S. and Wescot, D.W. (1994). Water quality for agriculture, FAO Irrigation and Drainage Paper 29. Rome, Italy.

Baloch, Q.B.; Chachar, Q.I.and Tareen, M.N. (2008). Effect of foliar application of macro and micro nutrients on production of green chilies (Capsicum annuum L.). J. Agric. Tech., 4(2): 177-184.

Bernal, M.; Cases, R.; Picorel, R. and Yruela, I. (2007). Foliar and root $\mathrm{Cu}$ supply affect differently $\mathrm{Fe}$ and Zn-uptake and photosynthetic activity in soybean plants. Environ. Exp. Botany, 60: 145-150.

Borowiec, M.; pogañska, P. and Hoffman,J.(2007). Biodegradability of the compounds introduced with microelement fertilizers into the environment. Pol. J. Chem. Tech., 9: 38-41.

British Pharmacopoeia, (1963). Determination of Volatile Oils in Drugs. PP. 101-112. The Pharmaceutical press. London

Cakmak, I. (2008). Enrichment of cereal grains with zinc: Agronomic or genetic biofortification? Plant Soil 302:1-17.

Cottenie, A.; Verlso, M.; Kilkens, L.; Velghe, G. and Camerlynck, R. (1982). Chemical Analysis of Plants and Soils. Lab. Agroch. State Univ. Gent, Belgium.

Duke, A.J.(1986). Handbook of Legumes of World Economic Importance, Plemus Press, New York and London. pp: 345.

El-Din, A.A.E. and Hendawy, S.F. (2010). Effect of dry yeast and compost tea on growth and oil content of Borago officinalis plant. Research Journal of Agriculture and Biological Sciences, 6(4):424-430.

El-Saady, A. S. M. (2012). Impact of foliar spraying of some organic substances and micronutrients on wheat grown on clayey soil. J. Soil Sci. and Agric. Eng., Mansoura Univ., 3 (3), 349 - 360.
El-Sherbeny, S.E.; Hendawy, S.F.;Youssef, A.A.; Naguib, N.Y. and Hussein, M.S. (2012). Response of turnip (Brassica rapa) plants to minerals or organic fertilizers treatments. Journal of Applied Sciences Research. 8(2):628-34.

Faizy, S.E.D.; Mashali, S.A. ; Youssef, S.M. and Elmahdy, Sh.M. (2017). Study of wheat response to nitrogen fertilization, micronutrients and their effects on some soil available macronutrients. J. Sus. Agric. Sci. 43(1): 55- 64

Gad El-Hak, S.H.; Ahmed, A.M. and Moustafa, Y.M.M. (2012). Effect of Foliar Application with Two Antioxidants and Humic Acid on Growth, Yield and Yield Components of Peas (Pisum sativum L.) Journal of Horticultural Science \& Ornamental Plants 4 (3), 318-328.

Gomaa, M.A.; Radwan, F.I.; Kandil, E.E. and El-Zweek, S.M.A. (2015). Effect of some macro and micronutrients application methods on productivity and quality of Wheat (Triticum aestivum L.). Middle East J. Agric. Res., 4(1): 1-11.

Hänsch, R. and Mendel, R.R.(2009). Physiological functions of mineral micronutrients $(\mathrm{Cu}, \mathrm{Zn}, \mathrm{Mn}$, $\mathrm{Fe}, \mathrm{Ni}, \mathrm{Mo}, \mathrm{B}, \mathrm{Cl})$. Current Opinion of Plant Biology 12:259-266.

Hendawy, S. F. (2008). Comparative study of organic and mineral fertilization on Plantago arenaria plant. J. Appl. Sci. Res. 4(5): 500-506.

Ibrahim ,H. A. and Ibrahim, S.M. (2014). Effect of some organic extracts on essential nutrients uptake of sugar beet under saline conditions. Research Journal of Agriculture and Biological Sciences. 10(1):53-64.

Kabata-Pendias, A. and Pendias, H.(1992). Trace Elements in Soils and Plants. 2nd ed. USA: CRC Press, Inc. Boca Raton, Florida.

Kaya, M.; Atak, M.; Mahmood, K.; Çiftçi, C.Y. and Özcan, S. (2005). Effect of pre-sowing seed treatment with zinc and foliar spray of humic acids on yield of common bean (Phaseolus vulgaris L.). Int. J. Agri. Biol., 6(7): 875-878.

Komosa A.;Chohura, P. and Roszyk, J. (2005). Effect of temperature and the application time of a nutrient on content of iron available in iron chelates. Zesz. Nauk. AR Wroclaw, Rol., 515: 259-265. (in Polish)

Kozik,E.; Tyksinski, W. and Komosa, A.( 2008). Effect of chelated and mineral forms of micronutrients on their content in leaves and the yield of lettuce. PART I. MANGANESE. Acta Sci. Pol., Hortorum Cultus 7(1), 73-82

Lucena, J.J. (2003). Fe chelates for remediation of $\mathrm{Fe}$ chlorosis in Strategy I plants. J. PlantNutr., 26:1969-1984.

Mahmoud,E.; ElGizawy, E. and Geries, L. (2014). Effect of compost extract, N2 fixing bacteria and nitrogen levels applications on soil properties and onion crop.

Marschner H (1995). Mineral Nutrition of Higher Plants. 2ed. New York: Academic Press. 
Mehrafarin, A.; Rezazadeh, Sh.; Naghdi B. H.; Noormohammadi, Gh. , Zand, E. and Qaderi, A. ( 2010). Review on Biology, Cultivation and Biotechnology of Fenugreek (Trigonella foenumgraecum L.) as a Valuable Medicinal Plant and Multipurpose. Journal of Medicinal Plant.10(37):623.

Misra, A.; Dwivedi, S.; Srivastava, A.K.; Tewari, D.K.; Khan, A. and Kumar, R. (2006). Low iron stress nutrition for evaluation of Fe-efficient genotype physiology, photosynthesis, and essential monoterpene oil(s) yield of Ocimum sanctum. Photosyntetica, 44 (3): 474-477.

Narwal, R.P.; Dahiya, R.R. ; Malik, R.S. and Kala, R. (2012). Influence of genetic variability on zinc, iron and manganese responses in wheat. Journal of Geochemical Exploration 121:45-48.

Nicholson, G. 1984. Methods of Soil, Plant and Water Analysis. N Z Forest Service. FRI Bulletin No. 70.

Page, A.L.; Miller, R.H. and Keeney, D.R. (1984). Methods of Soil Analysis. part 2: Chemical and Microbiological Properties. Second edition. Agronomy J. 9: 2, Am. Soc. Agron. Inc., Soil Sci. Soc. Am. Inc. Pub. Madison, Wisconsin, USA.

Raza, S.A.; Ali, S.; Chahill, Z.S. and Iqbal, R.M. (2014). Response of foliar application of boron on wheat (Triticum aestivum L) crop in calcareous soils of Pakistan. Acad. J. Agric. Res. 2(3):106-109.

Reeves, R. D. and.Baker, A. J. M (2000). Metal Accumulating In: Raskin, I.B., Ensley, D. (Eds.), Phytoremediation of Toxic Metals: Using Plants to Clean Up the Environment. Wiley, New York. pp:193 - 229.
Rodríguez-Ortíz, J .C.; Valdez-Cepeda, R. D.; LaraMireles, J. L.; Rodríguez-Fuentes, H.; VázquezAlvarado, R. E; Magallanes-Quintanar, R. and García-Hernández, J. L. (2006). Soil nitrogen fertilization effects on phytoextraction of cadmium and lead by tobacco (Nicotiana tabacum L.). Biorem10:105-114.

Shao, G.; Chen, M.; Wang, W.; Mou, R. and Zhang G (2007). Iron nutrition affects cadmium accumulation and toxicity in rice plants. Plant Growth Reg., 53: 33-42.

Stepien, A. and Wojtkowiak, K. (2016).Effect of foliar application of $\mathrm{Cu}, \mathrm{Zn}$, and $\mathrm{Mn}$ on yield and quality indicators of winter wheat grain. Chilean journal of agricultural research 76(2):220-226.

Svecnjak, Z., M. Jenel, M. Bujan, D. Vitali, and I.V. Dragojevic. 2013). Trace element concentrations in the grain of wheat cultivars as affected by nitrogen fertilization. Agricultural and Food Science 22:445451.

Ure, A. M. (1995). Methods of analysis for heavy metals in soils. In: "Heavy Metals in Soils, Alloway", B. J., Blacke Academic and Professional, an imprint of Chapman \& Hall, Wester cleddens Road, Bishopbriggs, Glasgow G64 2NZ,UK.,:58-102.

Wojtkowiak, K.; Stepien A.;Warechowska, M. and Raczkowski, M. (2014) Content of copper, iron, manganese and zinc in typical light brown soil and spring triticale grain depending on a fertilization system. Journal of Elementology 19, 833-844.

Wreesmann C. (1996). Chelated micro-nutrients for soilless culture. ISOSC Proc.559-572.

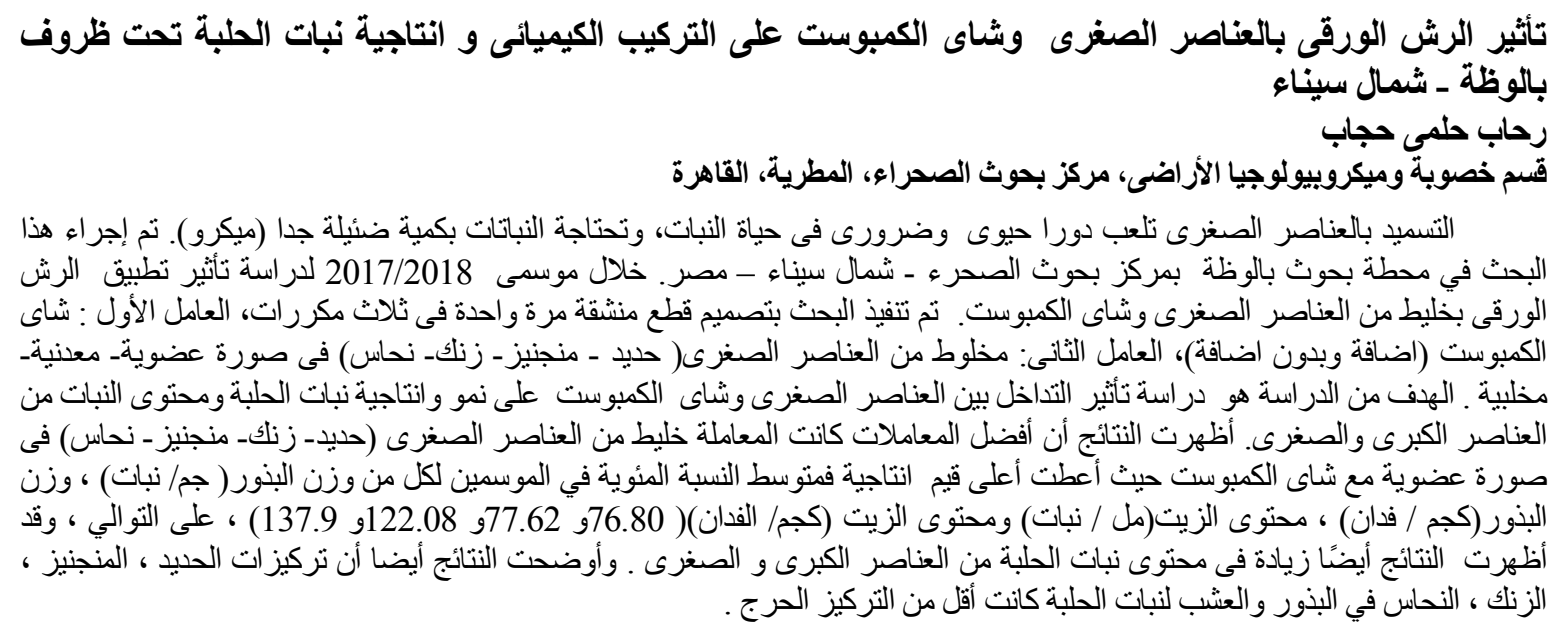

